\title{
Obituary
}

\section{Prof. Wilhelm Ostwald}

W ILHELM (FRIEDRICH) OSTWALD, whose death took place on April 4, was the most notable and widely known figure in the history of physical chemistry during the quarter of a century which preceded his retirement from active academic work in 1905. Of this branch of science, in fact, he may quite properly be called the founder.

Born at Riga on Sept. 2, 1853, and educated at the recently established Realgymnasium in his native town, Ostwald entered the University of Dorpat in January 1872. In 1877 he became magister and privatdozent, and in $\mathbf{1 8 7 8}$ he obtained the degree of doctor. Three years later, he accepted a call to the chair of chemistry in the Polytechnic at Riga, where he remained until 1887 . It was at Riga that Ostwald's amazing powers as an organiser, thinker, investigator, and teacher had, for the first time, free opportunity to unfold themselves and to grow in strength. There he organised his teaching on a physico-chemical basis, and his aim was to train his students to be scientific thinkers. It was to Ostwald's laboratory at Riga that Arrhenius came in 1885, seeking help and sympathetic understanding of his work.

In 1887, Ostwald was invited to fill the chair of physical chemistry at Leipzig in succession to G. Wiedemann, and it was in Leipzig, first in the buildings of the Agricultural Institute and then, from 1897 onwards, in the new Physical Chemistry Institute in the Linnéstrasse, that Ostwald's greatest work as a teacher, writer, investigator, and inspirer of research was carried out; and it was during his Leipzig period that his intellectual and creative powers attained their zenith.

Ostwald retired from his chair at Leipzig in 1905 and, in the same year, he was nominated by the German Emperor as first exchange professor to America. In 1909 he was awarded the Nobel prize in chemistry.

In a short notice it is not possible to give more than an indication of some of Ostwald's scientific and literary achievements. In his work as an investigator, Ostwald, by his own hands or with the help of a large number of students who flocked from all parts of the world to his laboratory, laid the foundations of large sections of physical chemistry. Problems of chemical affinity, strength of acids as determined by density measurements, distribution between bases, effect on hydrolysis of methyl acetate, etc., were the subjects which first attracted his attention; and he discovered, independently of Arrhenius, that the conductivity and chemical activity of acids run parallel. Then came the development of electrochemical studies-electrical conductivity and electromotive force measurements as methods of studying chemical activity, solubilities, etc. - and out of these studies came the dilution law and Ostwald's devotion to energetics. Lastly, in the laboratories at Leipzig, the foundations of the study of catalysis were well and truly laid. By no other leader in chemical science has such a wide range and variety of scientific interests been manifested.

Great, however, as were Ostwald's experimental contributions to physical chemistry, his work as teacher and as champion of what might then be called the new learning (van't Hoff's theory of solutions, Arrhenius's theory of electrolytic dissociation, etc.) was perhaps of still greater value for the advance of science. An enthusiastic lover of his subject, Ostwald was possessed by the spirit of the missionary and the teacher. To the joy of creating and acquiring knowledge was added the equally great joy of passing on his knowledge and mental outlook to others. Ostwald was a master both of the spoken and of the written word, and once his orderly and clear-thinking brain had arranged his ideas, he could give rapid and unhesitating expression to them in clear and smoothflowing language. His extraordinary memory, moreover, never failed to supply him with apt illustrations with which to adorn an argument.

In the early days at Riga, Ostwald collected together all that was known in the department of physical chemistry, and so gave to all serious students his "Lehrbuch der allgemeinen Chemie" (1885-1887); and in order to promote the study of physical chemistry and to provide an organ for its expression, he founded, in collaboration with van't Hoff, the Zeitschrift für physikalische Chemie. From that time, book after book-his "Grundriss", his "Elektrochemie", his "Hand- und Hilfsbuch", his "Grundlinien der anorganischen Chemie", his "Schule der Chemie", etc.-poured from his pen. To the all-compelling power of Ostwald's personality, to his burning enthusiasm, and to the freshness, breadth, and inspiration of his personal teaching and of his writings, physical chemistry owes a very special debt.

By the end of last century, Ostwald's interest in a specialised branch of science had developed, quite naturally as he felt, into an interest in generalised knowledge or philosophy; and, in 1902, he published his "Vorlesungen über Naturphilosophie", which attracted much attention at the time and received the warm appreciation of William James. As was natural with Ostwald, there followed on the publication of his "Vorlesungen " the founding of the periodical, Annalen der Naturphilosophie. So Ostwald, the apostle of physical chemistry, became the apostle of the doctrine of energy as the fundamental basis of reality.

Although Ostwald had never been much interested in industrial chemistry, he felt it to be his patriotic duty to make his country independent of others for the supply of the nitric acid necessary for the manufacture of explosives, and he turned his attention, therefore, to the production of nitric acid by the catalytic oxidation of ammonia. The process which he developed was the main source of Germany's supply of nitric acid during the War.

Ostwald was a man of large mind and large heart ; 
he spoke his mind freely and always put forward his views with enthusiasm and conviction, but he neither scorned nor regarded lightly the honestly held views of others. His honesty of purpose, his enthusiasms, his freshness of mind, and the variety of his interests gave to all intercourse with him a charm which impressed all those who had the privilege to partake of it. To his purely scientific interests he added an intense interest in music and painting, and the exercise of these two arts was the means whereby a tired and sometimes overwrought brain became rested and refreshed. To his interest in painting is no doubt due the interest which, during the later years of his life, he took in the theory of colour, his views regarding which he has expounded in his book, "Physikalische Farben. lehre ", and in other books and memoirs.

Alex. Findlay.

\section{Dr. H. T. Ferrar}

The death of Hartley Travers Ferrar at the comparatively early age of about fifty-two years was announced in London on April 19. Leaving Oundle in 1898, he entered Sidney Sussex College, Cambridge, and took a second class in the Natural Science Tripos in 1901. Besides being captain of his College boat club he rowed in the University trials, and it was when stepping out of an eight at Henley that he was offered a place as geologist to Capt. Scott's First Expedition to the Antarctic. The chief scenes of his labours on the expedition were in South Victoria Land, where the great Ferrar Glacier was named after him.

On his return to Cambridge in 1904, Ferrar was elected a fellow of the Geological Society and spent several months in writing up his observations. Living beneath the same roof with him at this time, and discussing almost daily his many problems, I learned to appreciate-possibly as few could who had not accompanied Scott-those sterling qualities that had enabled him to accomplish so much, and won him so many lifelong friends.

In the autumn of 1905, Ferrar joined the Egyptian Survey, and before Christmas had made a long camel trip into the Eastern Desert beyond Edfu. By April 1906 he was in the Western Desert (Sellima Oasis) beginning to interest himself in water-supply. In late 1907 he commenced field-work in Upper Egypt on the movements of subsoil waters, with particular reference to their effects upon cotton and other crops ; and this study was extended to Lower Egypt in subsequent years. Results were published as a Survey Department paper in 1911. During 1910-11 he made a series of experiments, in association with the Department of Agriculture, on the effects of movements of the water-table on the cultivation of cotton in the Delta, in the course of which he set out many lines of tube wells and recorded thousands of observations. The experiments proved that there was (up to a limit) a steady increase in the crop yield with increase in the thickness of soil above the water-table. The findings were issued as a Survey Department paper in 1912. During this period also he visited the oil-fields.

Somewhere about 1912, Ferrar retired from the
Egyptian Survey and proceeded to New Zealand, his wife's home country. The outbreak of war saw him in Egypt again, with the New Zealand Forces, and later he became an efficient map-officer attached to the Australian Flying Contingent in Palestine.

In 1919, Ferrar was appointed geologist to the New Zealand Survey (Department of Scientific and Industrial Research) in which he had risen to the position of assistant director at the time of his death. Amongst other publications, an important Bulletin (No. 27, New Series, 1925), written mostly by himself, " On the Geology of the Whangarei-Bay of Islands Subdivision, Kaipara Division", describes the results of the survey of 1905 square miles in North Auckland and deals largely with mineral deposits. In his latest outstanding work (Bull. No. 33, New Series, 1929), "On the Soils of Irrigation Areas in Otago Central ", his Egyptian experiences were invaluable, as shown by his discussion of the irrigation problems. His soils are classified into series, classes and types, and such subjects as climate, drainage, soil-profile, youthful and mature soils are considered.

It was largely on the strength of this last publication that, in February last, Ferrar was awarded the degree of D.Sc. (Diploma) by the University of New Zealand. Besides his official publications, some thirty papers on different subjects were contributed to scientific journals in Great Britain, Egypt, and New Zealand.

In May 1931 old memories were revived when the Discovery called in at Wellington on its way to southern latitudes. Bernard Smith.

WE regret to announce the following deaths :

Dr. Albert P. Brigham, professor emeritus of geology at Colgate University, president in 1918-19 of the American National Council of Geography Teachers, on April 1, aged seventy-six years.

Mr. Donald R. Dickey, a research associate of the California Institute of Technology, who was an authority on the birds and mammals of North and Central America, on April 16, aged forty-five years.

Dr. B. K. Emerson, for forty-seven years professor of geology at Amherst College, and president in 1899 of the Geological Society of America, on April 7, aged eighty-eight years.

Prof. C. S. Hastings, professor and emeritus professor of physics at Yale University since 1884 and a member of the U.S. National Academy of Sciences, a well-known designer of astronomical telescope objectives, aged eighty-three years.

Sir Thomas Legge, C.B.E., for nearly thirty years senior medical officer of factories at the Home Office and afterwards medical adviser to the social insurance section of the Trades Union Congress, who took a leading part in the promotion of industrial health in Great Britain, on May 7, aged seventy years.

The Hon. Dr. William Pember Reeves, formerly Agent-General and afterwards High Commissioner for New Zealand, who was director in 1908-19 of the London School of Economics, on May 15, aged seventy-five years. 